Supporting Information

\title{
Synthesis of Poly(dithienogermole)s
}

Masashi Nakamura, ${ }^{\dagger}$ Yousuke Ooyama, ${ }^{\dagger}$ Shinjiro Hayakawa, ${ }^{\dagger}$ Makoto Nishino,${ }^{\ddagger}$ Joji Ohshita $^{\dagger} *$

†Department of Applied Chemistry, Graduate School of Engineering, Hiroshima University, Higashi-Hiroshima 639-8527, Japan

Analytical \& Measuring Instruments Division, Shimadzu Corporation, 1, Nishinokyo-Kuwabaracho, Nakagyo-Ku, Kyoto 604-8511, Japan

Experimental Details

p S2

${ }^{1} \mathrm{H}$ and ${ }^{13} \mathrm{C}$ NMR Spectra

p S7

Frontier Orbital Profiles

p S16

UV-vis absorption and PL spectra

p S16 


\section{EXPERIMENTAL}

General

All reactions were carried out in dry argon. THF, diethyl ether, and toluene, which were used as the reaction solvents, were distilled from $\mathrm{CaH}_{2}$ and stored over activated molecular sieves in the dark until use. NMR spectra were recorded on Varian 400-MR and Varian system 500-MR spectrometers. EI-mass spectra were recorded on a Shimadzu QP-2020A spectrometer, while those with high resolution were performed on a JMS-T100GCv spectrometer at N-BARD, Hiroshima University. ESI- and APCI-mass spectra were obtained by a Thermo Fisher Scientific LTQ Orbitrap XL spectrometer at N-BARD, Hiroshima University. UV-vis absorption and PL (photoluminescence) spectra were measured on Hitachi U-3210 and HORIBA FluoroMax-4 spectrophotometers, respectively. PL quantum yields were determined on a HORIBA FluoroMax-4 spectrofluorometer using a calibrated integrating sphere system $\left(\lambda_{\mathrm{ex}}=320 \mathrm{~nm}\right)$. GPC was carried out using serially connected Shodex KF2001 and KF2002 columns and THF as the eluent. XRF analysis was carried out on a Shimadzu EDX-7000 energy dispersive X-ray fluorescence spectrometer. XRF analysis at HiSOR was carried out on the BL11 of HiSOR, and L $\alpha$ line from Ge was utilized for quantification because of its characteristic energy is similar to that of $S \mathrm{~K} \alpha$. X-ray diffraction data of dDTGH were collected at $-150{ }^{\circ} \mathrm{C}$ on a Rigaku R-AXIS RAPID diffractometer using graphite-monochromated $\mathrm{MoK} \alpha$ radiation. The structures were solved by Direct Method (SHELXS-97) and expanded using Fourier techniques. Non-hydrogen atoms were refined anisotropically, whereas hydrogen atoms were included but not refined (SHELXL-97). All other calculations were performed using the CRYSTAL-STRUCTURE crystallographic software package of Rigaku Corporation.

\section{Preparation of pDTGH}

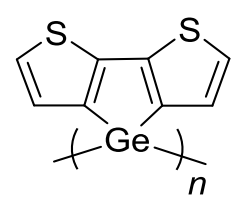

In a $50 \mathrm{~mL}$ three-neck round-bottom flask fitted with a mechanical stirrer were placed sodium $(0.202 \mathrm{~g}, 8.78 \mathrm{mmol})$ and toluene $(5 \mathrm{~mL})$. The mixture was heated to reflux and vigorously stirred to form sodium dispersion. To this was added 4,4-dichlorodithienogermole (DTGClH) ${ }^{13}$ (0.880 g, $\left.2.86 \mathrm{mmol}\right)$ in toluene $(25 \mathrm{~mL})$. 
After stirring the mixture for $9 \mathrm{~h}$ at $110{ }^{\circ} \mathrm{C}$, the mixture was filtrated and the filtrated was concentrated to a half volume under reduced pressure. Methanol $(150 \mathrm{~mL})$ was added to the concentrated solution and the resulting mixture was stirred for $1 \mathrm{~h}$ then filtered. After evaporation of the solvent, the residue was reprecipitated from tetrahydrofuran/ethanol to provide $42.0 \mathrm{mg}$ (6\% yield) of PDTGH as a yellow solid: $\mathrm{mp}$ $>300{ }^{\circ} \mathrm{C}$; ${ }^{1} \mathrm{H}$ NMR ( $\delta$ in $\mathrm{d}_{8}$-THF, $400 \mathrm{MHz}$ ) 7.13 (br m, thiophene ring proton); ${ }^{13} \mathrm{C}$ NMR spectrum was not obtained due to the low solubility.

\section{Preparation of pDTGEt}<smiles>CCc1cc2c(s1)-c1sc(CC)cc1C1(CC1)C2(C)C</smiles>

Polymer pDTGEt was obtained in a fashion similar to that above using 4,4-dichloro-3,6-diethyldithienogermole (DTGCIEt) ${ }^{13}$ instead of DTGCIH, in $28 \%$ yield as a yellow solid: $\mathrm{mp}>300{ }^{\circ} \mathrm{C}$; ${ }^{1} \mathrm{H}$ NMR ( $\delta$ in $\mathrm{d}_{8}$-THF, $\left.400 \mathrm{MHz}\right) 1.21(6 \mathrm{H}$, br s, ethyl) $2.75\left(4 \mathrm{H}\right.$, br s, ethyl), $6.83\left(2 \mathrm{H}\right.$, br m, thiophene ring proton); ${ }^{13} \mathrm{C} \mathrm{NMR}(\delta$ in d8-THF, 100 MHz) 15.95-16.16 (m), 23.52-23.63 (m), 128.23-129.44 (brm), $139.06-139.16$ (brm), 142.50-142.62 (brm), 149.23-150.70 (brm); GPC $M_{\mathrm{n}}=4,600, M_{\mathrm{w}}$ $=10,800, M_{\mathrm{w}} / M_{\mathrm{n}}=2.3$.

\section{Preparation of pDTGOEt}

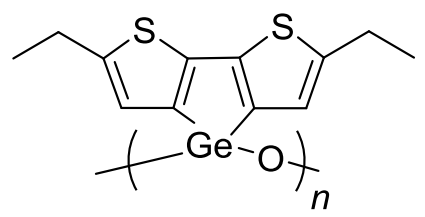

In a flask fitted with a Dean-Stark apparatus was placed trimethylamine $N$-oxide dihydrate $(34.0 \mathrm{mg}, 0.306 \mathrm{mmol})$ and toluene $(50 \mathrm{~mL})$. Approximately a half volume of toluene was distilled off for azeotropic removal of water. To this was added 60.1 mg of pDTGEt and the mixture was stirred at $110{ }^{\circ} \mathrm{C}$. After $6 \mathrm{~h}$, the mixture was cooled to room temperature and was poured into water. The organic layer was separated, and the aqueous layer was extracted with toluene. The organic layer and the extracts were combined and dried over anhydrous magnesium sulfate. After evaporation, the residue was reprecipitated from tetrahydrofuran/ethanol to provide 
$0.0230 \mathrm{~g}$ (37\% yield) of pDTGOEt as a yellow solid: $\mathrm{mp}>300{ }^{\circ} \mathrm{C} ;{ }^{1} \mathrm{H}$ NMR $(\delta$ in d8-THF, $500 \mathrm{MHz}) 1.16$ (6H, br m, ethyl) 2.64 (4H, br s, ethyl), 6.31 (2H, br m, thiophene ring proton); ${ }^{13} \mathrm{C}$ NMR ( $\delta$ in $\mathrm{d}_{8}$-THF, $\left.125 \mathrm{MHz}\right)$ 15.19-16.69 (m), 23.15-23.91 (m), 129.32-130.71 (brm), 134.87-135.96 (brm), 142.07-142.88 (brm), $148.27-149.08(\mathrm{brm}) ; \mathrm{GPC} M_{\mathrm{n}}=5,200, M_{\mathrm{w}}=8,300, M_{\mathrm{w}} / M_{\mathrm{n}}=1.6$.

\section{Preparation of DTGCIBu}

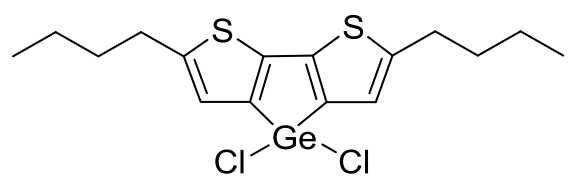

DTGCIBu was obtained in a fashion similar to that of homopolymers DTGCIH using 3,3'-dibromo-5,5'-dibutyl-2,2'-bithiophene as the monomer, in 41\% yield as a yellow oil: EI-MS $m / z=420\left[\mathrm{M}^{+}\right]\left({ }^{12} \mathrm{C}_{16}{ }^{1} \mathrm{H}_{20}{ }^{35} \mathrm{Cl}_{2}{ }^{74} \mathrm{Ge}^{32} \mathrm{~S}_{2}\right) ;{ }^{1} \mathrm{H}$ NMR $\left(\delta\right.$ in $\left.\mathrm{CDCl}_{3}, 500 \mathrm{MHz}\right)$ $0.95\left(6 \mathrm{H}, \mathrm{t}, J=7.4 \mathrm{~Hz}, \mathrm{CH}_{3}\right) 1.41\left(4 \mathrm{H}\right.$, sext, $\left.J=7.5 \mathrm{~Hz}, \mathrm{CH}_{2}\right), 1.67$ (4H, quint, $J=7.5$ $\left.\mathrm{Hz}, \mathrm{CH}_{2}\right) 2.81\left(4 \mathrm{H}, \mathrm{t}, J=7.4 \mathrm{~Hz}, \mathrm{CH}_{2}\right), 6.81\left(2 \mathrm{H}, \mathrm{s}\right.$, thiophene ring proton); ${ }^{13} \mathrm{C}$ NMR $(\delta$ in $\left.\mathrm{CDCl}_{3}, 125 \mathrm{MHz}\right) 13.90,22.25,30.09,33.78,123.99,124.64,132.54,144.85$, 149.16; Exact EI-MS Calcd for ${ }^{12} \mathrm{C}_{16}{ }^{1} \mathrm{H}_{20}{ }^{35} \mathrm{Cl}_{2}{ }^{74} \mathrm{Ge}^{32} \mathrm{~S}_{2}\left[\mathrm{M}^{+}\right]$419.95953. Found: 419.95920.

\section{Preparation of pDTGBu}

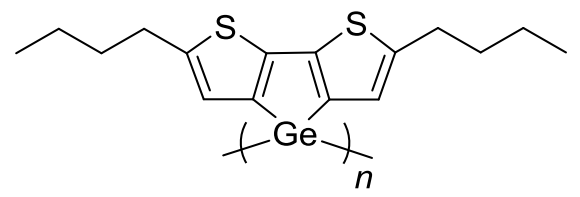

Polymer pDTGBu was obtained in a fashion similar to that of pDTGH using 4,4-dichloro-3,6-dibutyldithienogermole (DTGCIBu) instead of DTGCIH, in $31 \%$ yield as a yellow solid: $\mathrm{mp}>300{ }^{\circ} \mathrm{C} ;{ }^{1} \mathrm{H}$ NMR ( $\delta$ in $\mathrm{d}_{8}$-THF, $\left.400 \mathrm{MHz}\right) 0.93(6 \mathrm{H}$, br s, butyl) $1.39(8 \mathrm{H}$, br $\mathrm{m}$, butyl), $2.71(4 \mathrm{H}$, br s, butyl) $6.66(2 \mathrm{H}$, br $\mathrm{m}$, thiophene ring proton); ${ }^{13} \mathrm{C}$ NMR ( $\delta$ in $\left.\mathrm{d}_{8}-\mathrm{THF}, 100 \mathrm{MHz}\right)$ 13.84-14.45 (m), 22.57-23.48 (m), 29.92-31.04 (m), 34.07-35.01 (m), 127.59 (br), 145.67 (br), some carbon signals could not be seen, due to the low solubility; GPC $M_{\mathrm{n}}=3,200, M_{\mathrm{w}}=7,600, M_{\mathrm{w}} / M_{\mathrm{n}}=2.5$.

\section{Preparation of pDTGOBu}




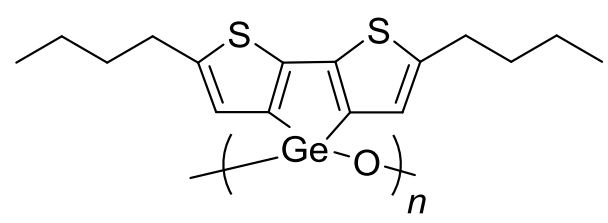

Polymer pDTGOBu was obtained in a fashion similar to that of pDTGOEt using pDTGBu instead of pDTGEt, in 55\% yield as a yellow solid: $\mathrm{mp}>300{ }^{\circ} \mathrm{C} ;{ }^{1} \mathrm{H} \mathrm{NMR}(\delta$ in $\mathrm{d}_{8}$-THF, $\left.400 \mathrm{MHz}\right) 0.93$ (6H, br s, butyl) 1.40 (8H, br m, butyl), 2.71 (4H, br s, butyl) $6.71\left(2 \mathrm{H}\right.$, br $\mathrm{m}$, thiophene ring proton); ${ }^{13} \mathrm{C}$ NMR ( $\delta$ in $\mathrm{d}_{8}$-THF, $\left.100 \mathrm{MHz}\right) 13.86-14.31$ (m), 22.64-23.38 (m), 29.57-30.76 (m), 33.88-35.07 (m), 130.74 (br), 146.99 (br); GPC $M_{\mathrm{n}}=2,200, M_{\mathrm{w}}=4,500, M_{\mathrm{w}} / M_{\mathrm{n}}=2.1$.

\section{Preparation of pDTGBu-GeBu-x}

Polymers pDTGBu-GeBu-x (x represents the loading mol\% of DTGCIBu for the preparation) were prepared by copolymerization of DTGCIBu and dibutyldichlorogermane in a fashion similar to preparation of homopolymers mentioned above: Date of pDTGBu-GeBu-50 ${ }^{1} \mathrm{H}$ NMR ( $\delta$ in $\mathrm{d}_{8}$-THF, $\left.400 \mathrm{MHz}\right) 0.93(17 \mathrm{H}$, br s, butyl) $1.40(19 \mathrm{H}$, br m, butyl), $2.81(8 \mathrm{H}$, br s, butyl $6.72(2 \mathrm{H}$, br $\mathrm{m}$, thiophene ring proton); ${ }^{13} \mathrm{C}$ NMR ( $\delta$ in $\left.\mathrm{d}_{8}-\mathrm{THF}, 100 \mathrm{MHz}\right)$ 13.52-14.40 (m), 22.46-23.28 (m), 26.03-27.83 (m), 29.60-30.12 (m), 30.12-31.56 (m), 33.95-35.15 (m), 127.89 (br), $145.65(\mathrm{br}) ;$ GPC $M_{\mathrm{n}}=2,000, M_{\mathrm{w}}=2,600, M_{\mathrm{w}} / M_{\mathrm{n}}=1.3$. Date of pDTGBu-GeBu-25 ${ }^{1} \mathrm{H}$ NMR ( $\delta$ in $\left.\mathrm{d}_{8}-\mathrm{THF}, 400 \mathrm{MHz}\right) 0.93(30 \mathrm{H}$, br s, butyl) $1.39(34 \mathrm{H}$, br m, butyl), 2.82 (4H, br s, butyl) $6.73\left(2 \mathrm{H}\right.$, br m, thiophene ring proton); ${ }^{13} \mathrm{C} \mathrm{NMR}$ ( $\delta$ in $\mathrm{d}_{8}-\mathrm{THF}, 100$ MHz) 13.89-14.49 (m), 22.82-23.40 (m), 27.07-28.15 (m), 30.30-32.02 (m), 34.27-35.43 (m), aromatic carbon signals could not be observed likely due to the signal broadening; GPC $M_{\mathrm{n}}=2,200, M_{\mathrm{w}}=3,300, M_{\mathrm{w}} / M_{\mathrm{n}}=1.5$.

\section{Preparation of dDTGH}




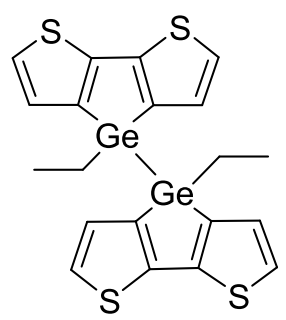

To a solution of $0.225 \mathrm{~g}(0.731 \mathrm{mmol})$ of 4,4-dichlorodithienogermole in $80 \mathrm{~mL}$ of diethyl ether was added dropwise a $0.2 \mathrm{M}$ ethylmagnesium bromide in diethyl ether solution ( $3.65 \mathrm{~mL}, 0.730 \mathrm{mmol}$ ) at $0{ }^{\circ} \mathrm{C}$, and mixture was stirred at $0{ }^{\circ} \mathrm{C}$ for $3 \mathrm{~h}$. After filteration, the solvent were removed under reduced pressure to give crude 1-chloro-1-ethyldithienogermole as a yellow solid. In a $50 \mathrm{~mL}$ three-neck round-bottom flask fitted with a mechanical stirrer were placed sodium $(0.034 \mathrm{~g}, 1.48$ $\mathrm{mmol})$ and toluene $(2 \mathrm{~mL})$. The mixture was heated to reflux and vigorously stirred to form sodium dispersion. To this was added 4-chloro-4-ethyldithienogermole in toluene $(8 \mathrm{~mL})$. After stirring the mixture for $5 \mathrm{~h}$ at $110{ }^{\circ} \mathrm{C}$, the mixture was filtrated and poured into a saturated aqueous ammonium chloride solution. The organic layer was separated, and the aqueous layer was extracted with toluene. The organic layer and the extracts were combined and dried over anhydrous magnesium sulfate. After evaporation, the residue was chromatographed on silica gel with dichloromethane as the eluent to afford dDTGH in $16 \%$ yield $(31.3 \mathrm{mg}, 0.0589 \mathrm{mmol})$ as a colorless solid: EI-MS $m / z=532\left[\mathrm{M}^{+}\right]\left({ }^{12} \mathrm{C}_{20}{ }^{1} \mathrm{H}_{18}{ }^{73} \mathrm{Ge}_{2}{ }^{32} \mathrm{~S}_{4}\right)$; mp 110.8-111.1 ${ }^{\circ} \mathrm{C} ;{ }^{1} \mathrm{H}$ NMR $\left(\delta\right.$ in $\mathrm{CDCl}_{3}$, $400 \mathrm{MHz}) 0.96\left(6 \mathrm{H}, \mathrm{t}, J=7.9 \mathrm{~Hz}, \mathrm{CH}_{3}\right) 1.20\left(4 \mathrm{H}, \mathrm{q}, J=7.9 \mathrm{~Hz}, \mathrm{CH}_{2}\right), 6.99(4 \mathrm{H}, \mathrm{d}, J=$ $4.9 \mathrm{~Hz}$, thiophene $\beta$-proton), $7.23\left(4 \mathrm{H}, \mathrm{d}, J=4.9 \mathrm{~Hz}\right.$, thiophene $\alpha$-proton); ${ }^{13} \mathrm{C} \mathrm{NMR}(\delta$ in THF, $100 \mathrm{MHz}$ ) 8.90, 10.24, 125.13, 129.76, 142.21, 146.40; Exact APCI-MS Calcd for ${ }^{12} \mathrm{C}_{20}{ }^{1} \mathrm{H}_{19}{ }^{74} \mathrm{Ge}_{2}{ }^{32} \mathrm{~S}_{4}\left[\mathrm{M}+\mathrm{H}^{+}\right]: 534.87877$. Found: 534.87775 . 


\section{${ }^{1} \mathrm{H}$ AND ${ }^{13} \mathrm{C}$ NMR SPECTRA}

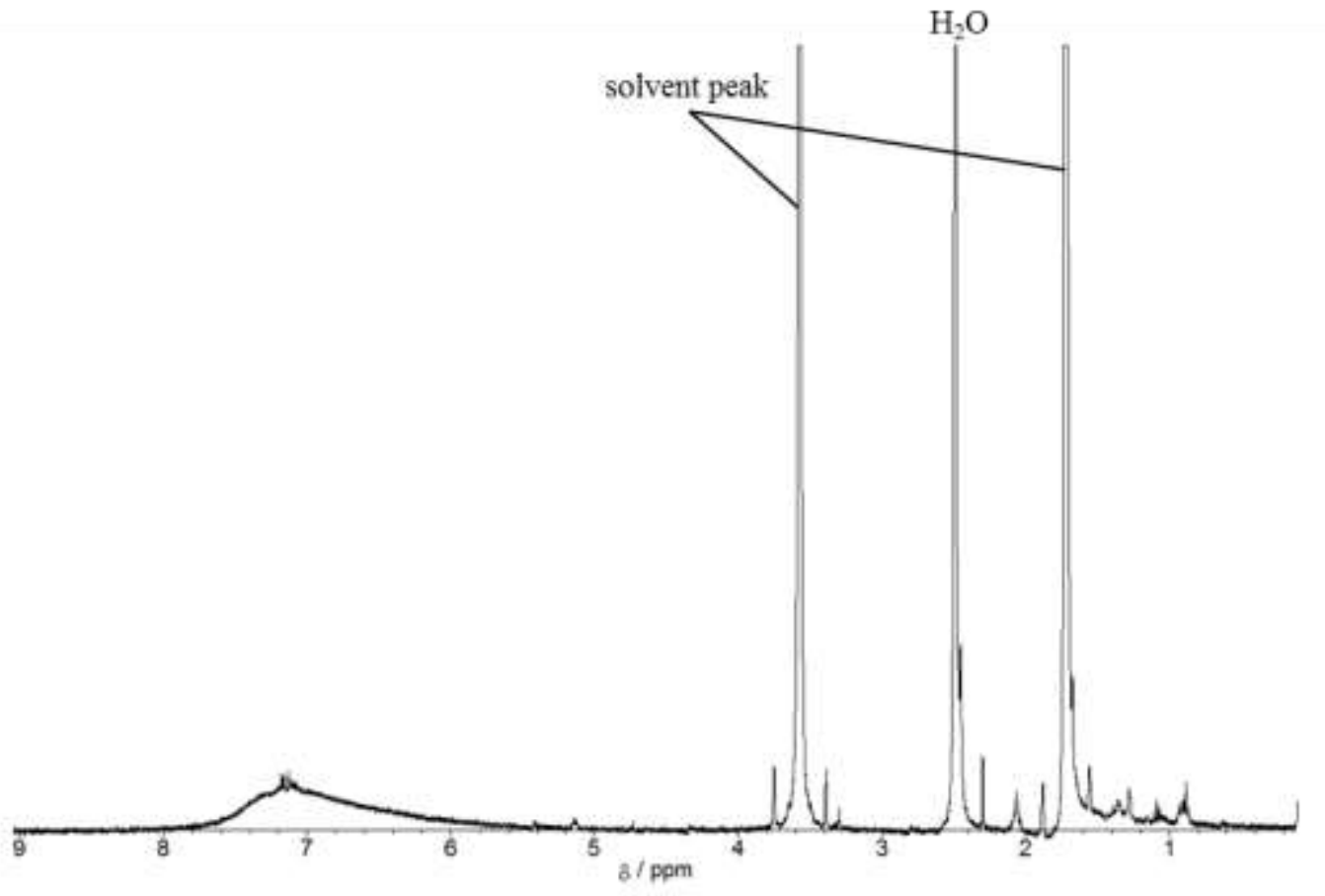

Figure S1. ${ }^{1} \mathrm{H}$ NMR spectrum of pDTGH in $\mathrm{d}_{8}$-THF.

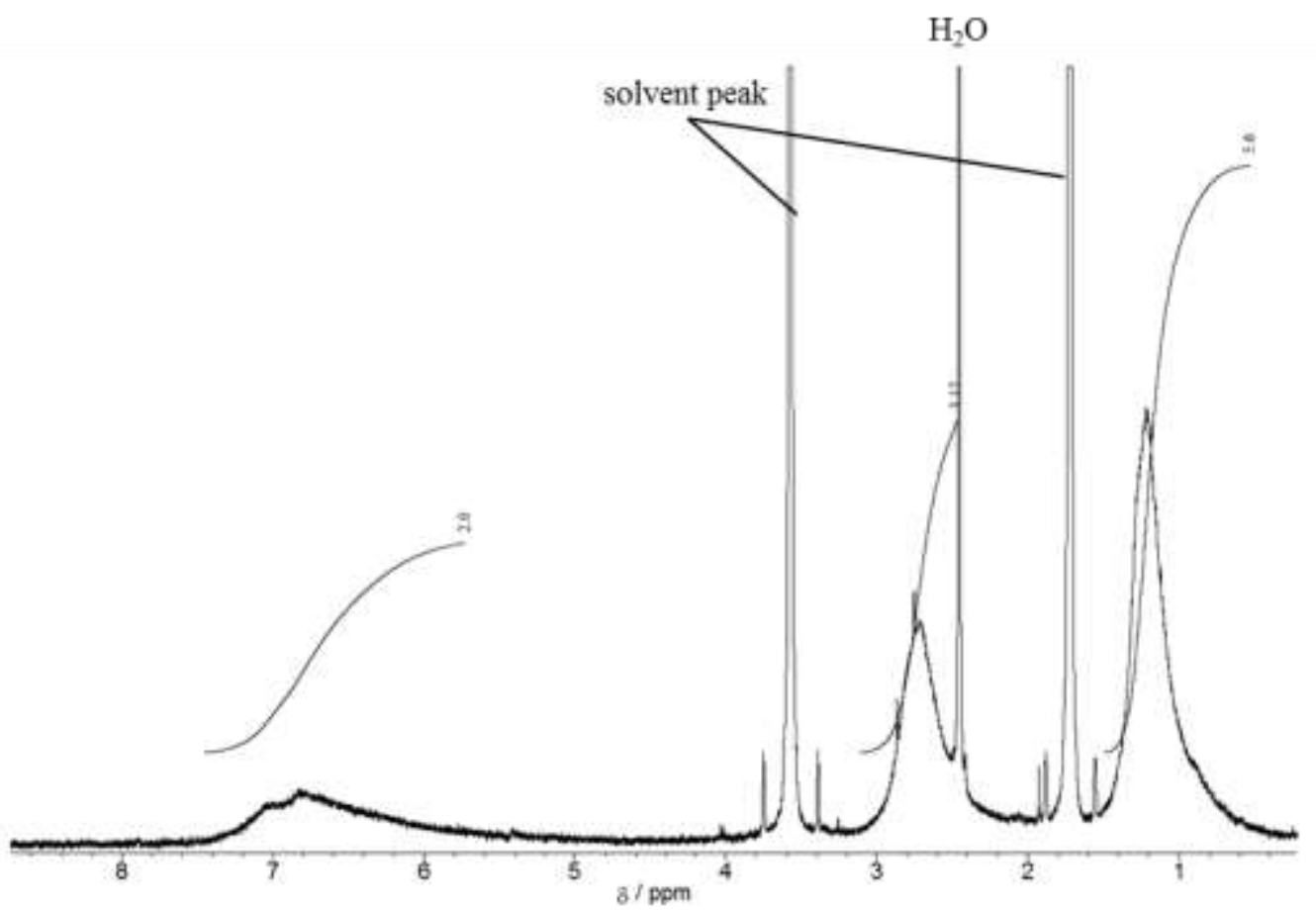

Figure S2. ${ }^{1} \mathrm{H}$ NMR spectrum of pDTGEt in $\mathrm{d}_{8}$-THF. 


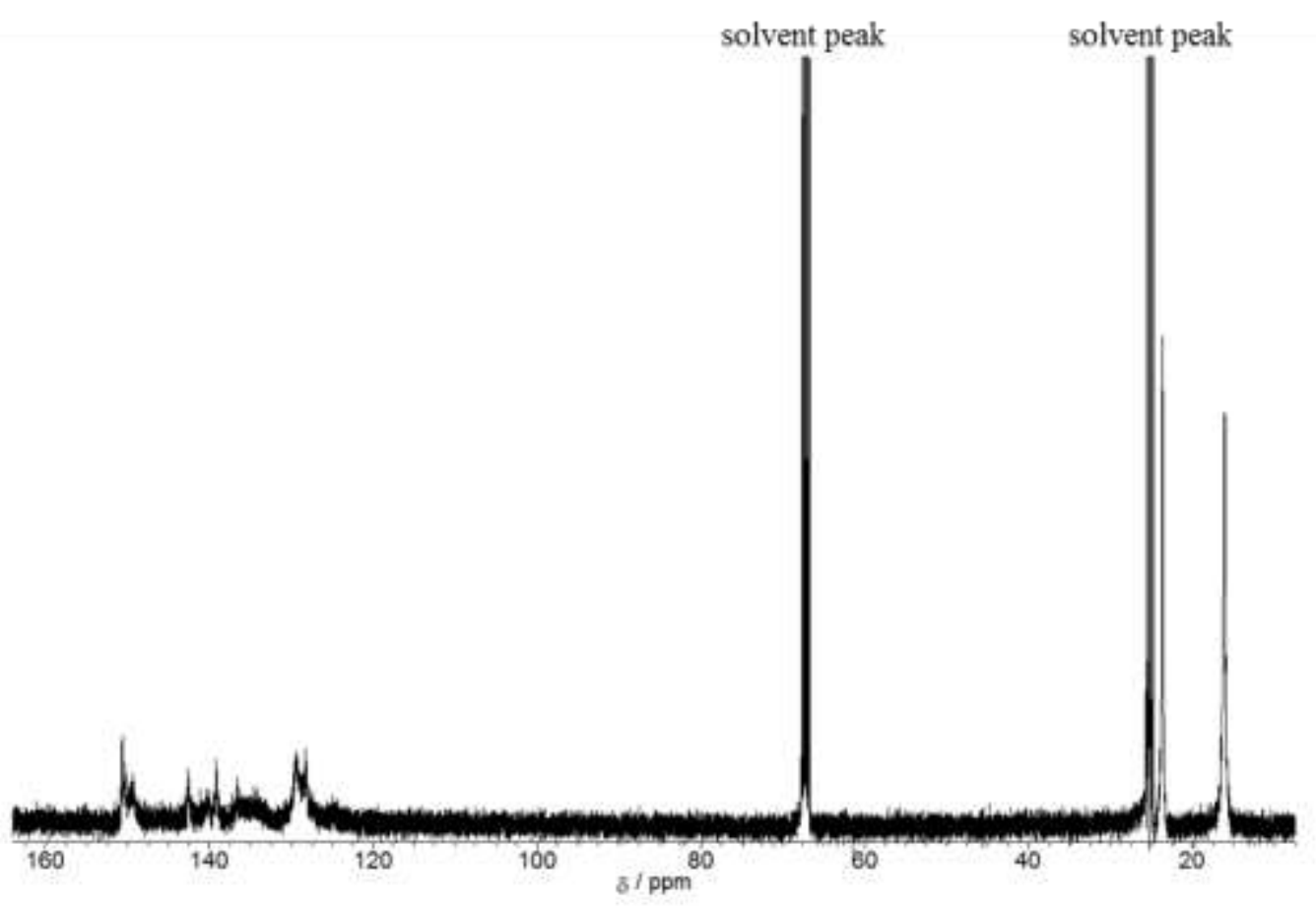

Figure S3. ${ }^{13} \mathrm{C}$ NMR spectrum of pDTGEt in $\mathrm{d}_{8}$-THF.

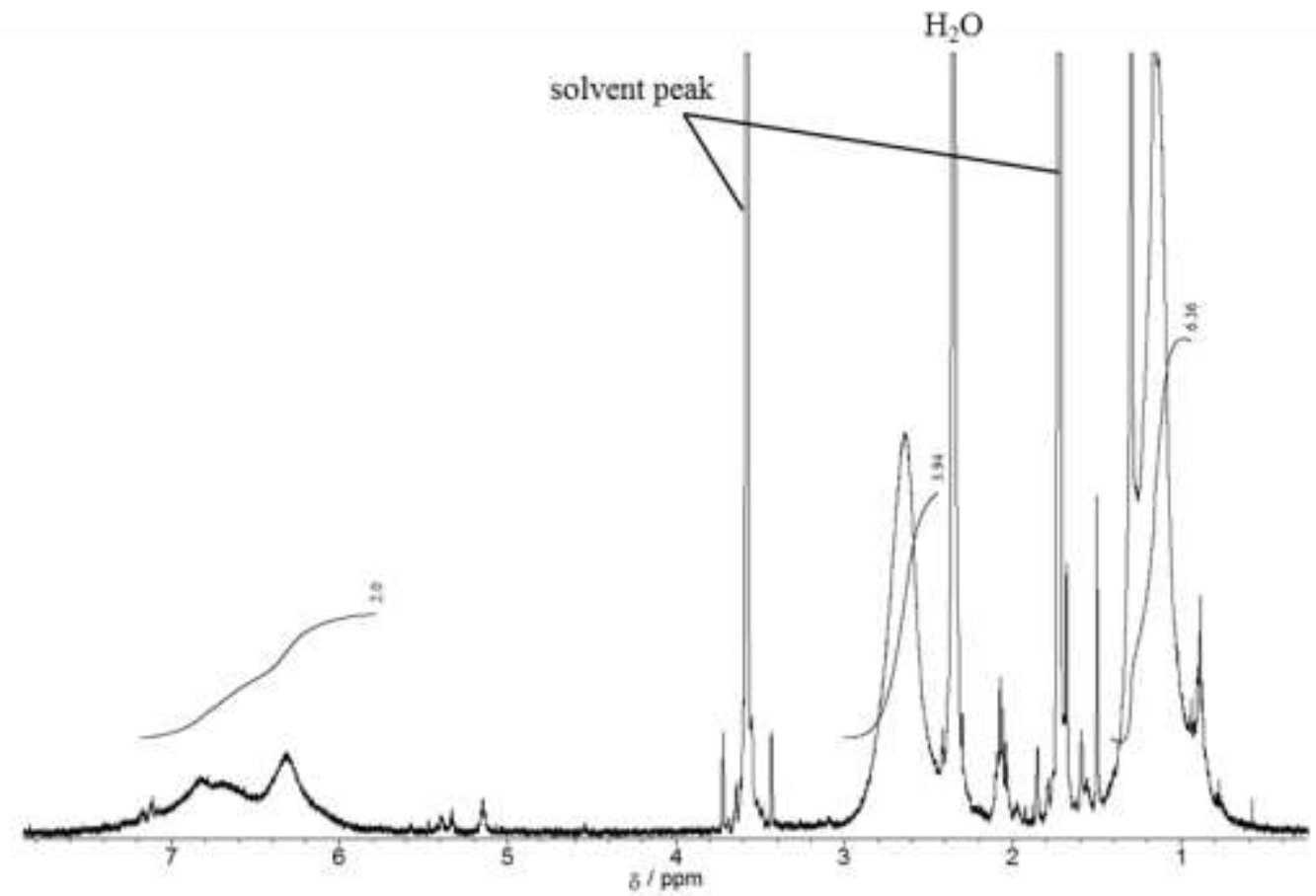

Figure S4. ${ }^{1} \mathrm{H}$ NMR spectrum of pDTGOEt in $\mathrm{d}_{8}$-THF. 


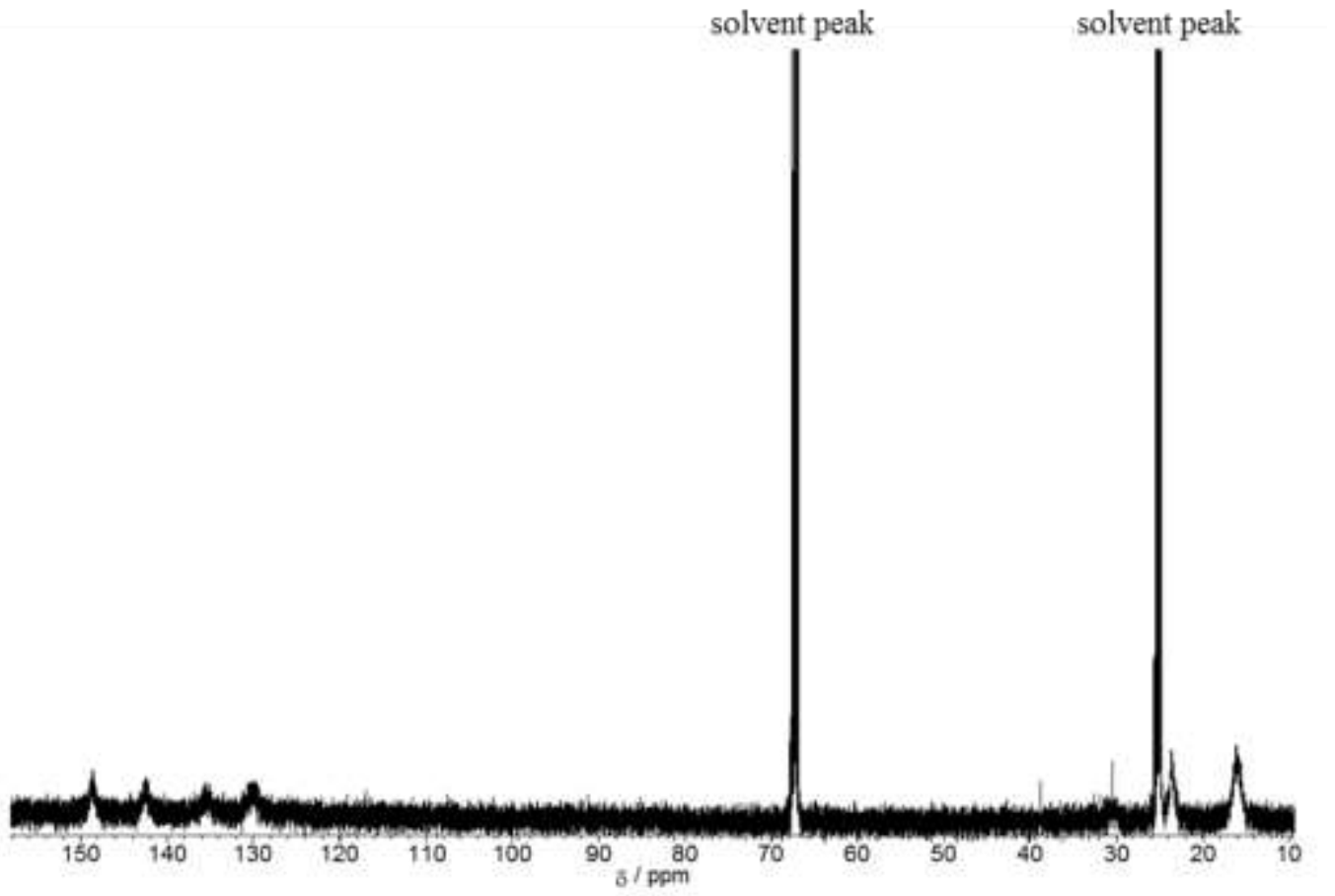

Figure S5. ${ }^{13} \mathrm{C}$ NMR spectrum of pDTGOEt in $\mathrm{d}_{8}$-THF.

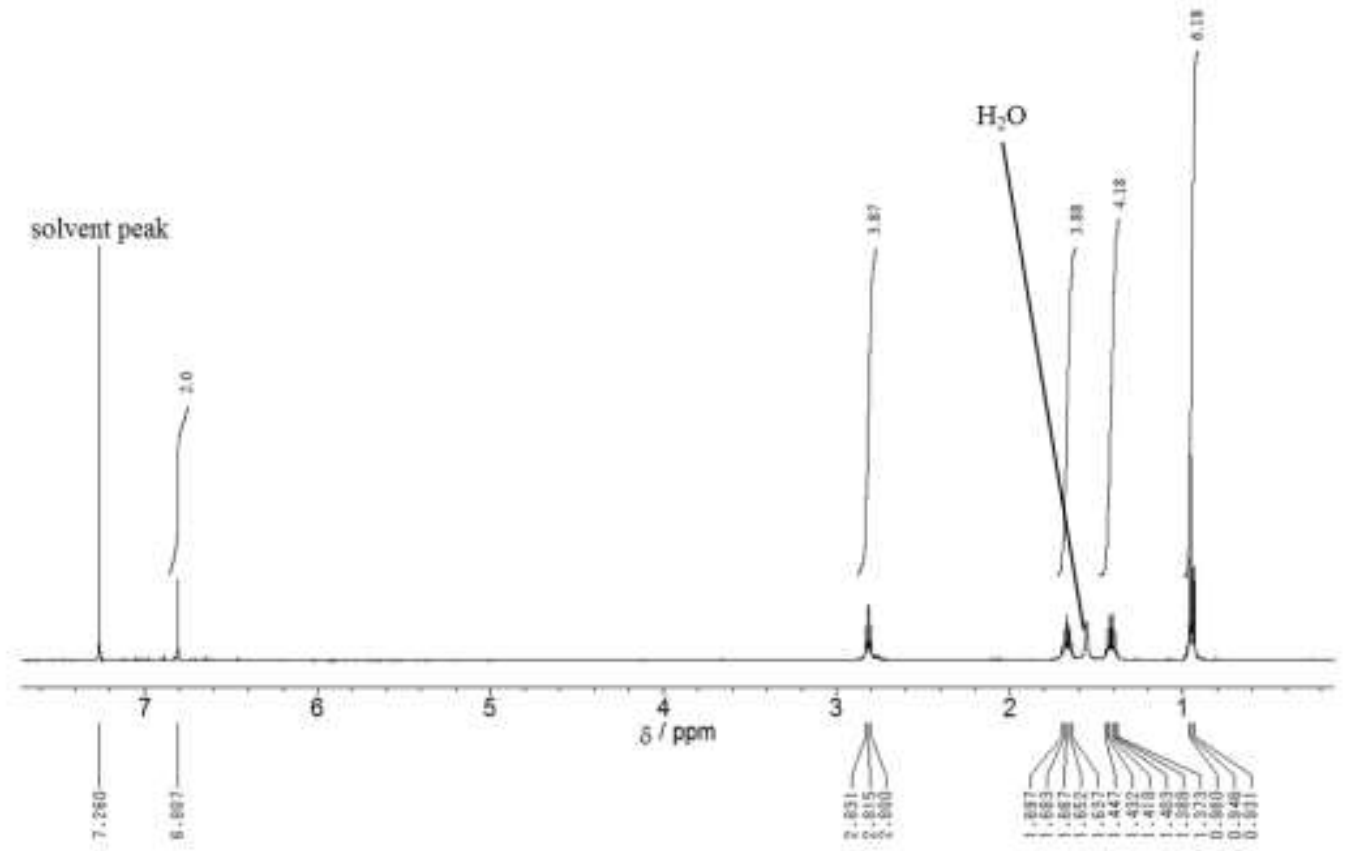

Figure S6. ${ }^{1} \mathrm{H}$ NMR spectrum of DTGCIBu in $\mathrm{CDCl}_{3}$. 


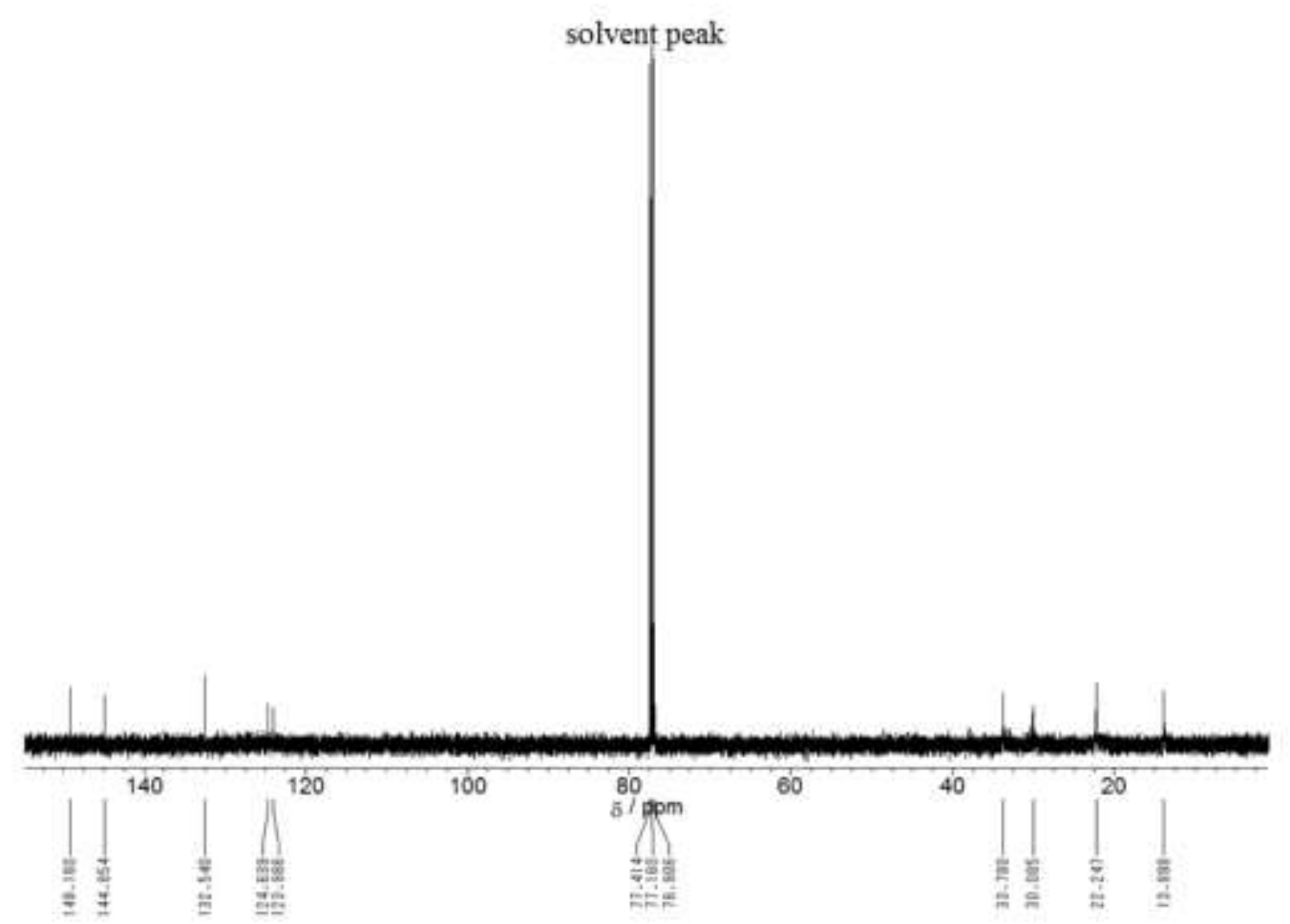

Figure S7. ${ }^{13} \mathrm{C}$ NMR spectrum of DTGCIBu in $\mathrm{CDCl}_{3}$.

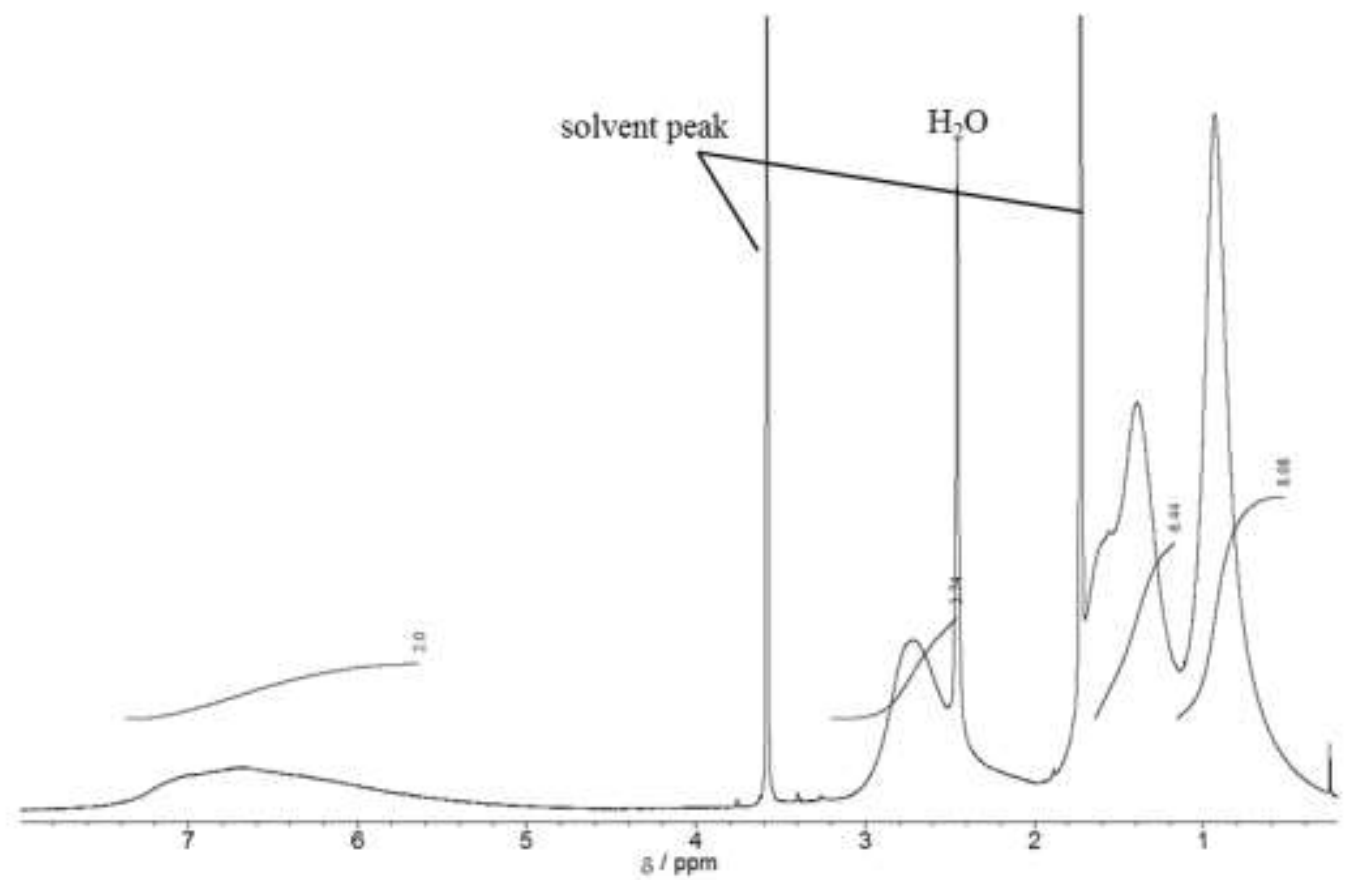

Figure S8. ${ }^{1} \mathrm{H}$ NMR spectrum of pDTGBu in $\mathrm{d}_{8}$-THF. 


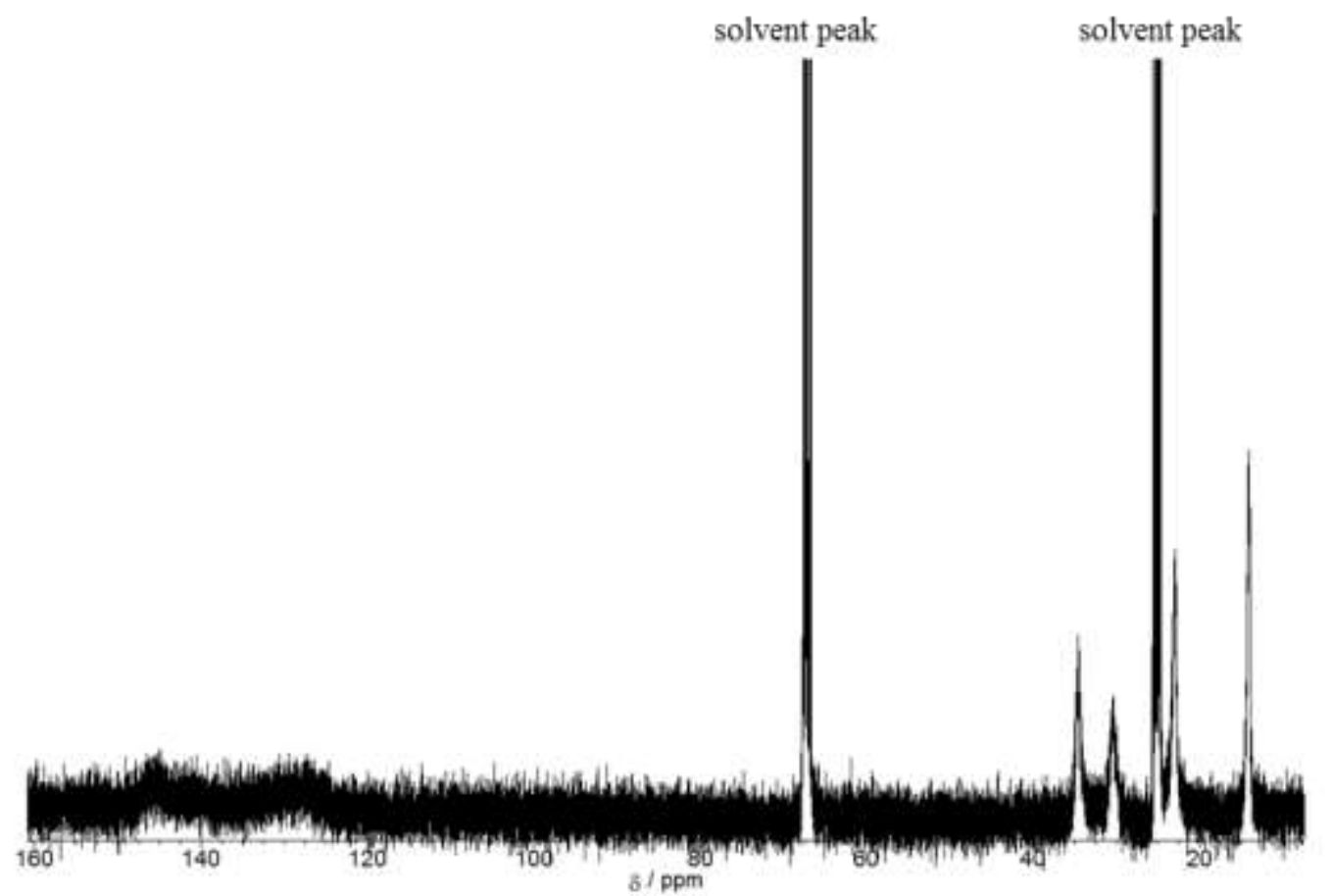

Figure S9. ${ }^{13} \mathrm{C}$ NMR spectrum of pDTGBu in $\mathrm{d}_{8}$-THF.

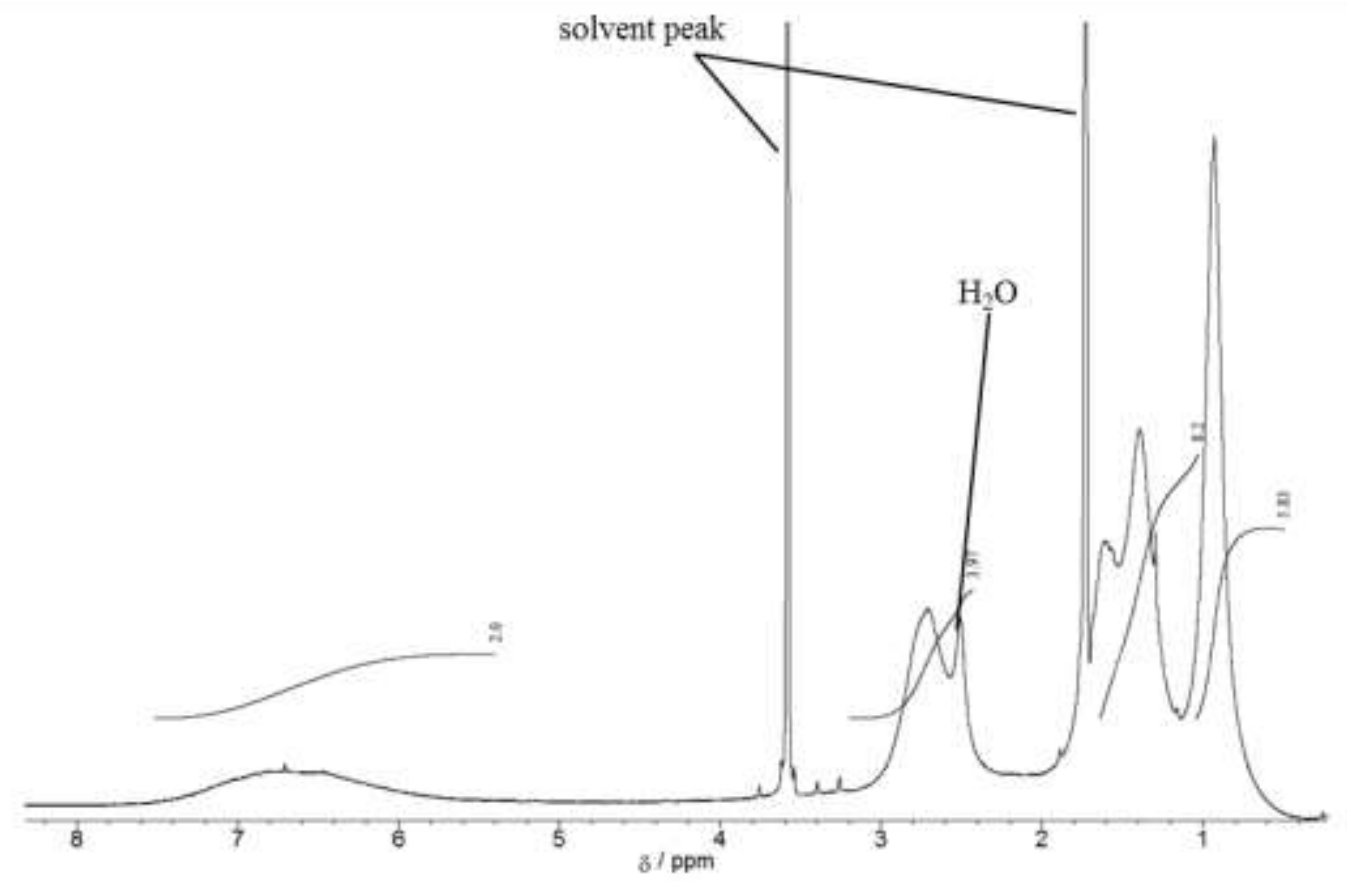

Figure S10. ${ }^{1} \mathrm{H}$ NMR spectrum of pDTGOBu in $\mathrm{d}_{8}$-THF. 


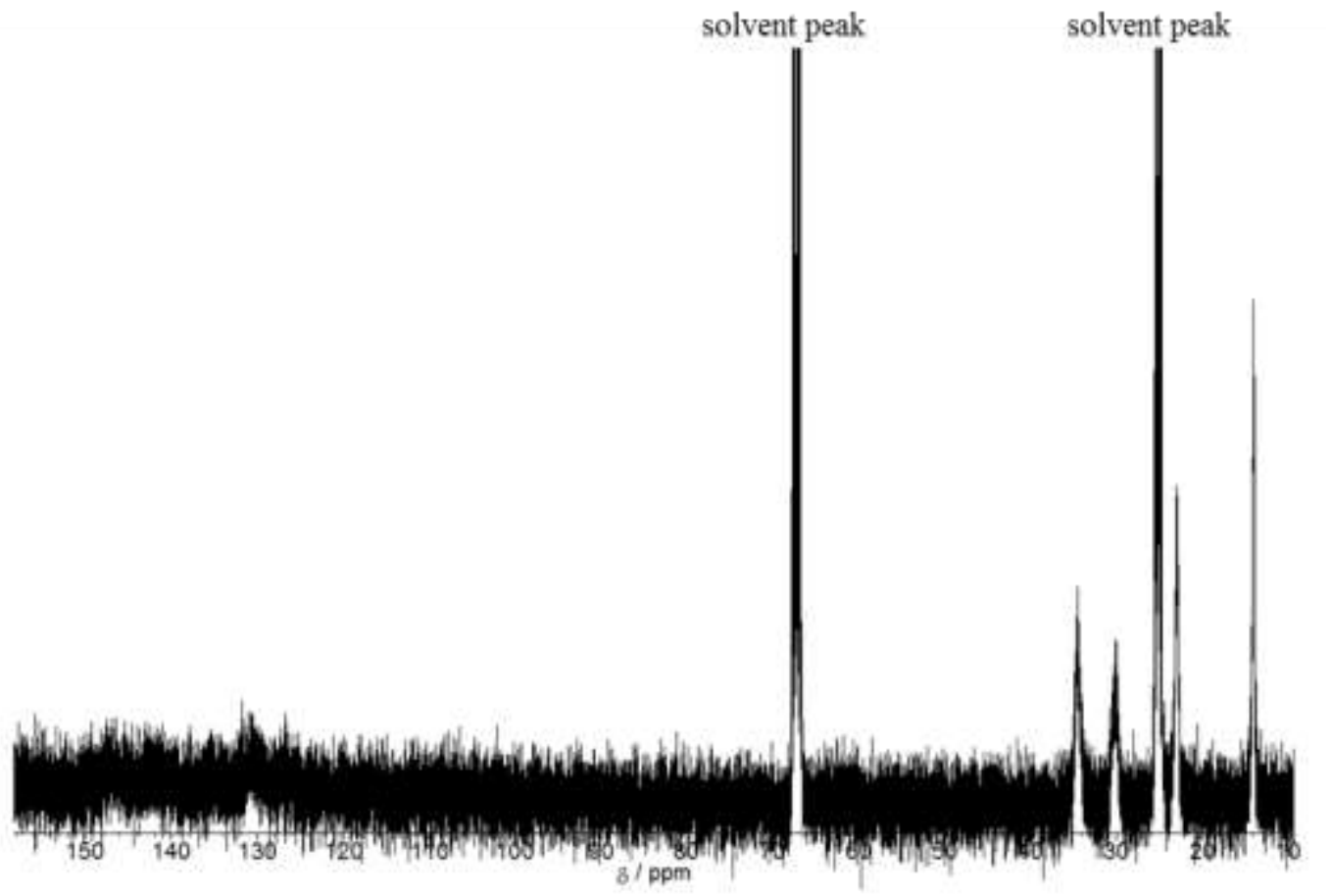

Figure S11. ${ }^{13} \mathrm{C}$ NMR spectrum of pDTGOBu in $\mathrm{d}_{8}$-THF.

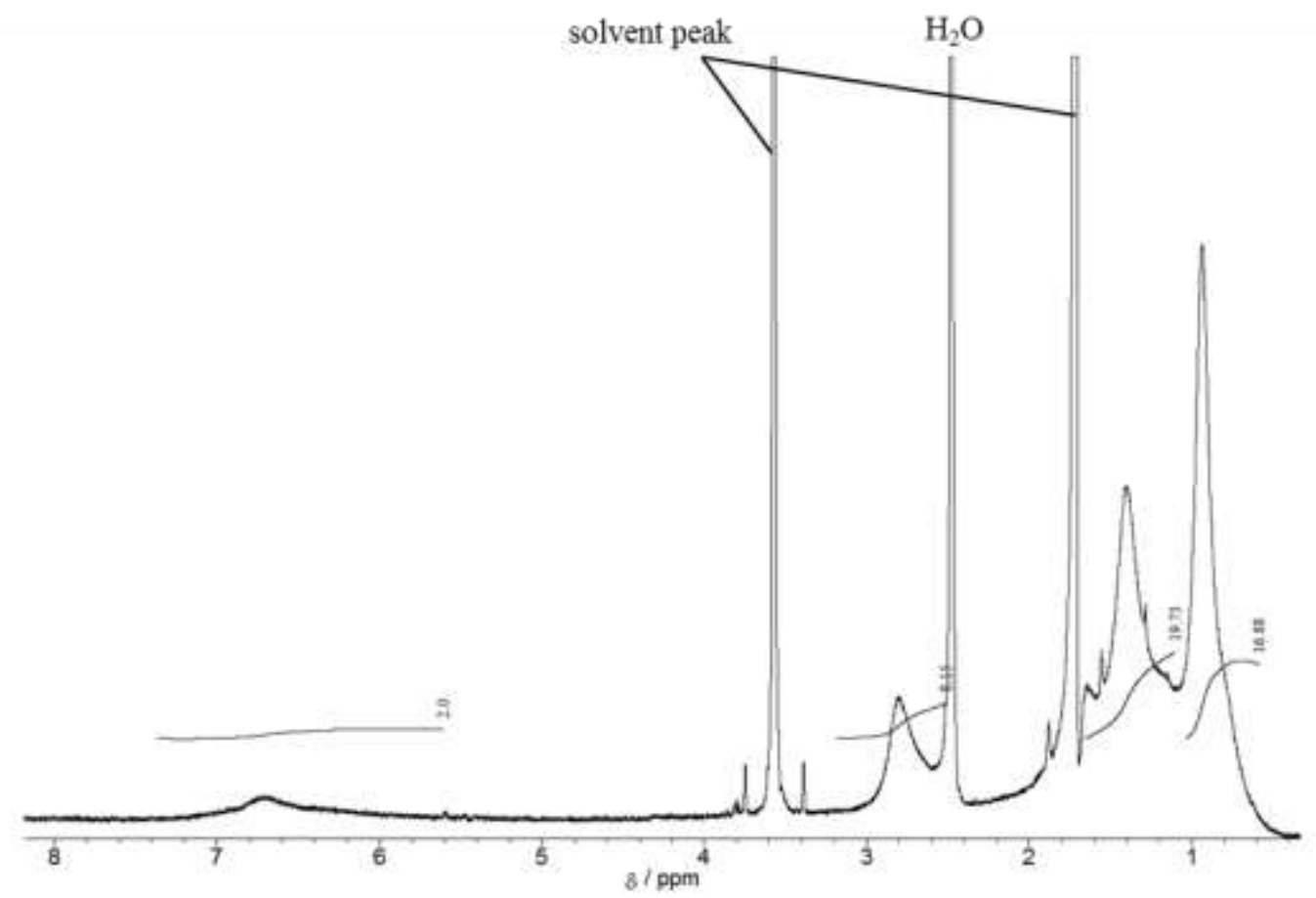

Figure S12. ${ }^{1} \mathrm{H}$ NMR spectrum of pDTGBu-GeBu-50 in $\mathrm{d}_{8}$-THF. 


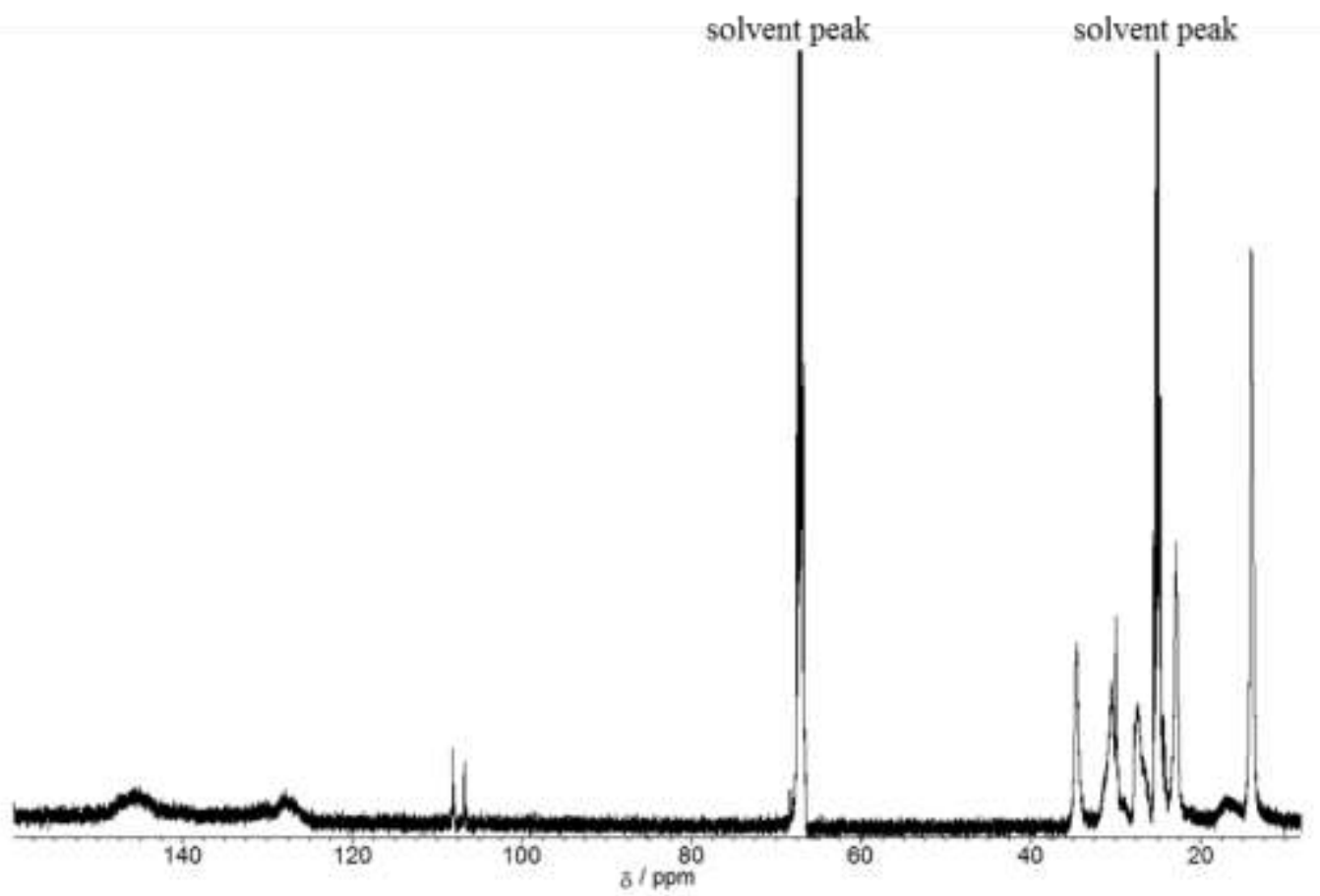

Figure S13. ${ }^{13} \mathrm{C}$ NMR spectrum of pDTGBu-GeBu-50 in $\mathrm{d}_{8}$-THF.

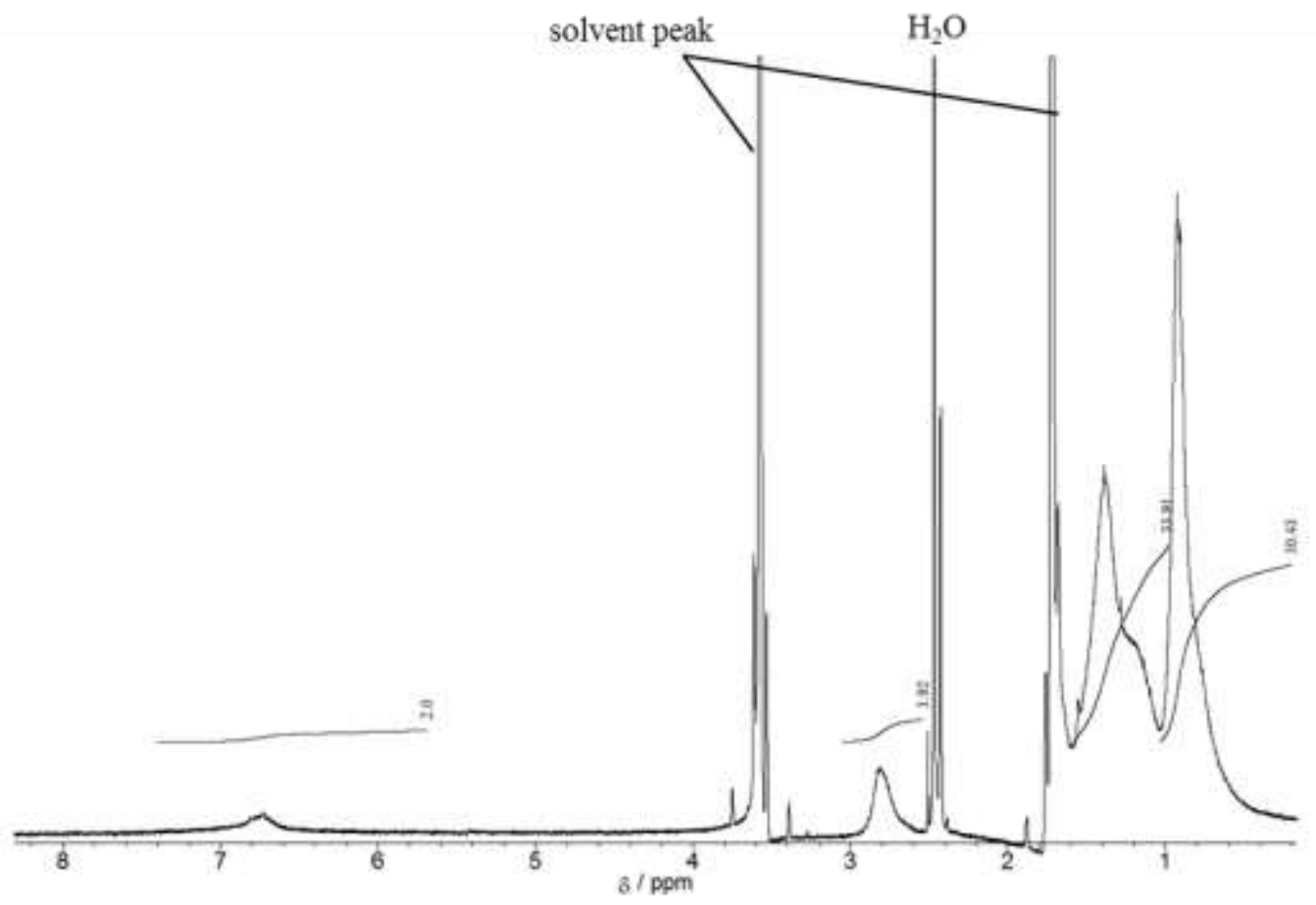

Figure S14. ${ }^{1} \mathrm{H}$ NMR spectrum of pDTGBu-GeBu-25 in $\mathrm{d}_{8}$-THF. 


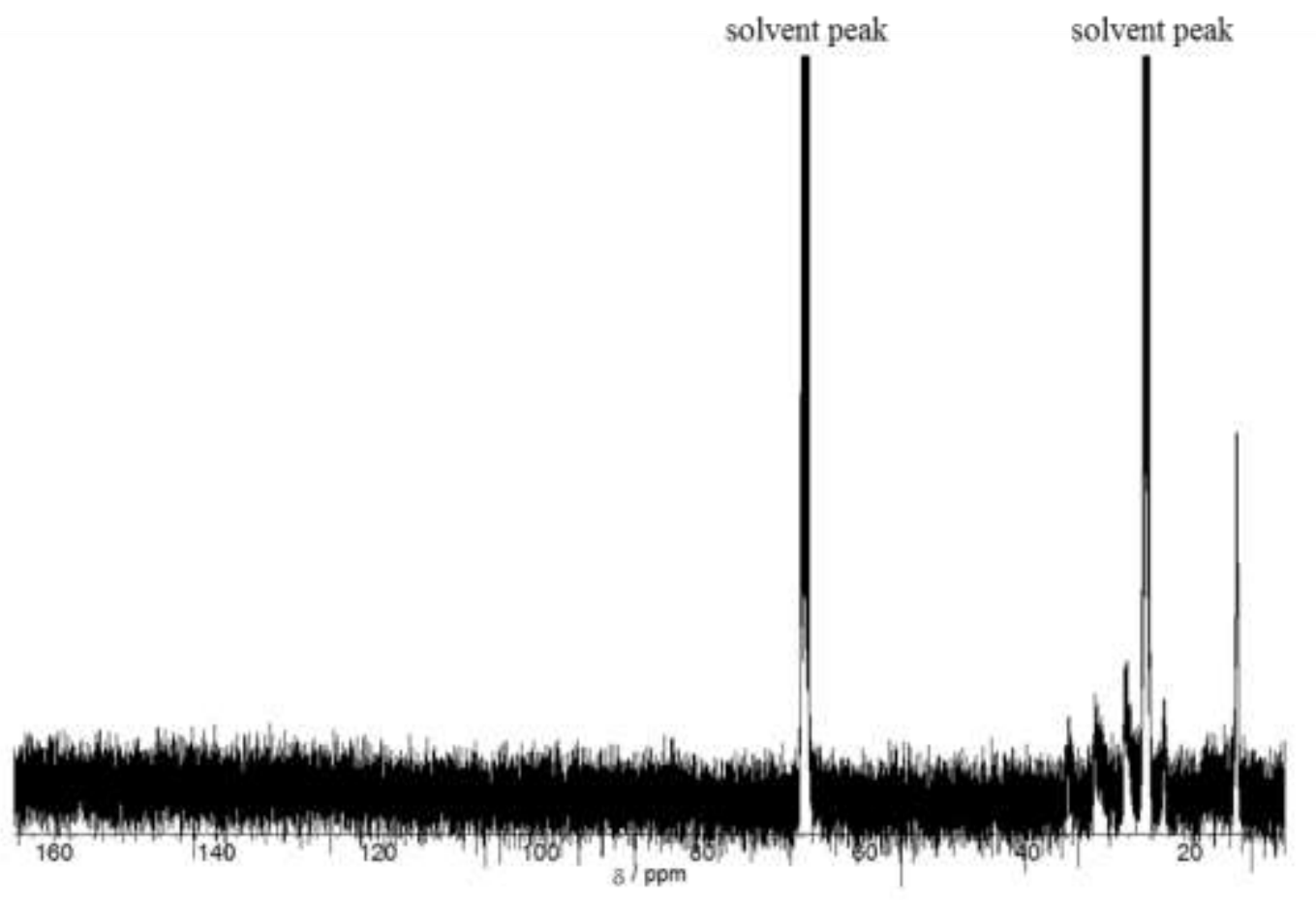

Figure S15. ${ }^{13} \mathrm{C}$ NMR spectrum of pDTGBu-GeBu-25 in $\mathrm{d}_{8}$-THF.

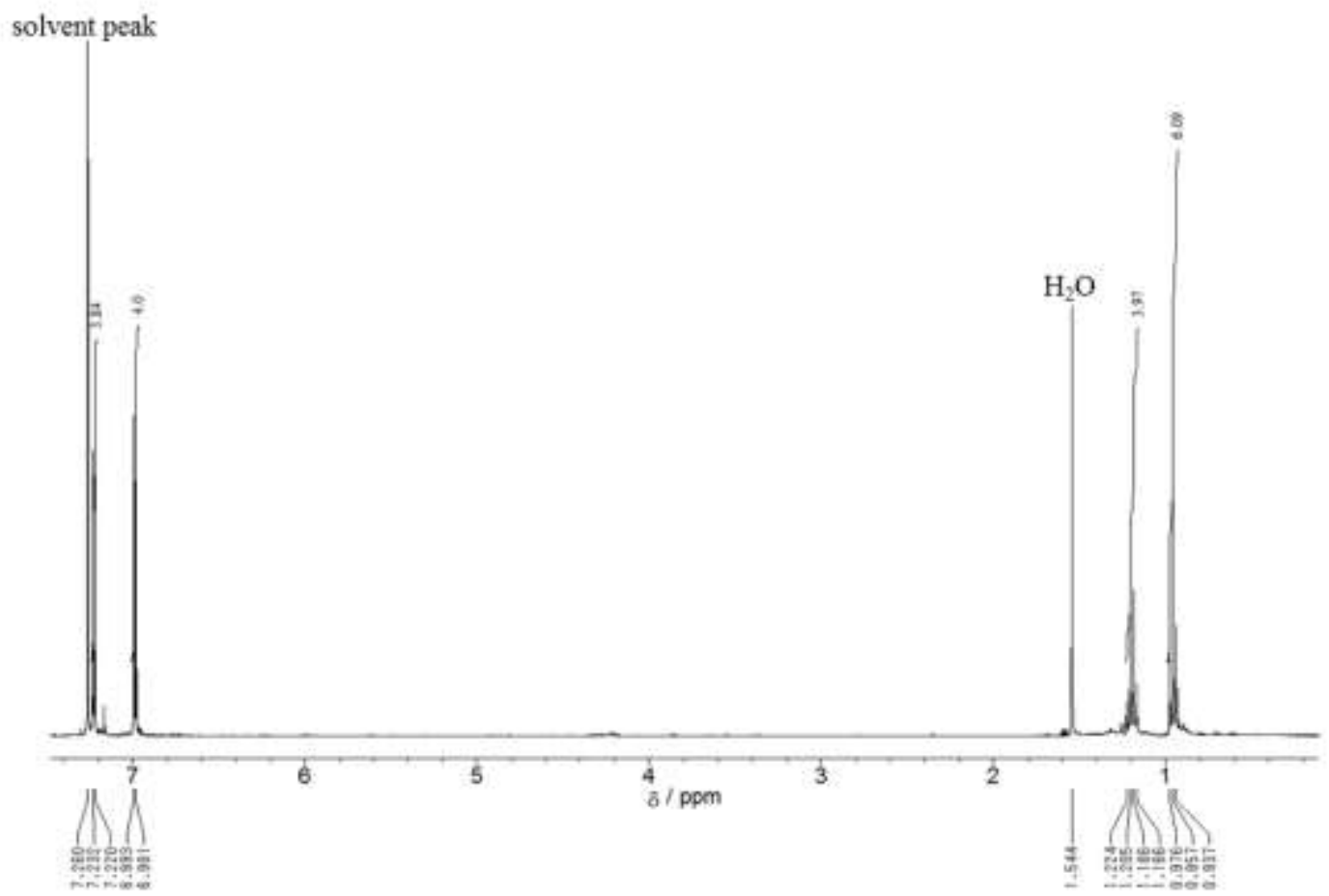

Figure S16. ${ }^{1} \mathrm{H}$ NMR spectrum of dDTGH in $\mathrm{CDCl}_{3}$. 


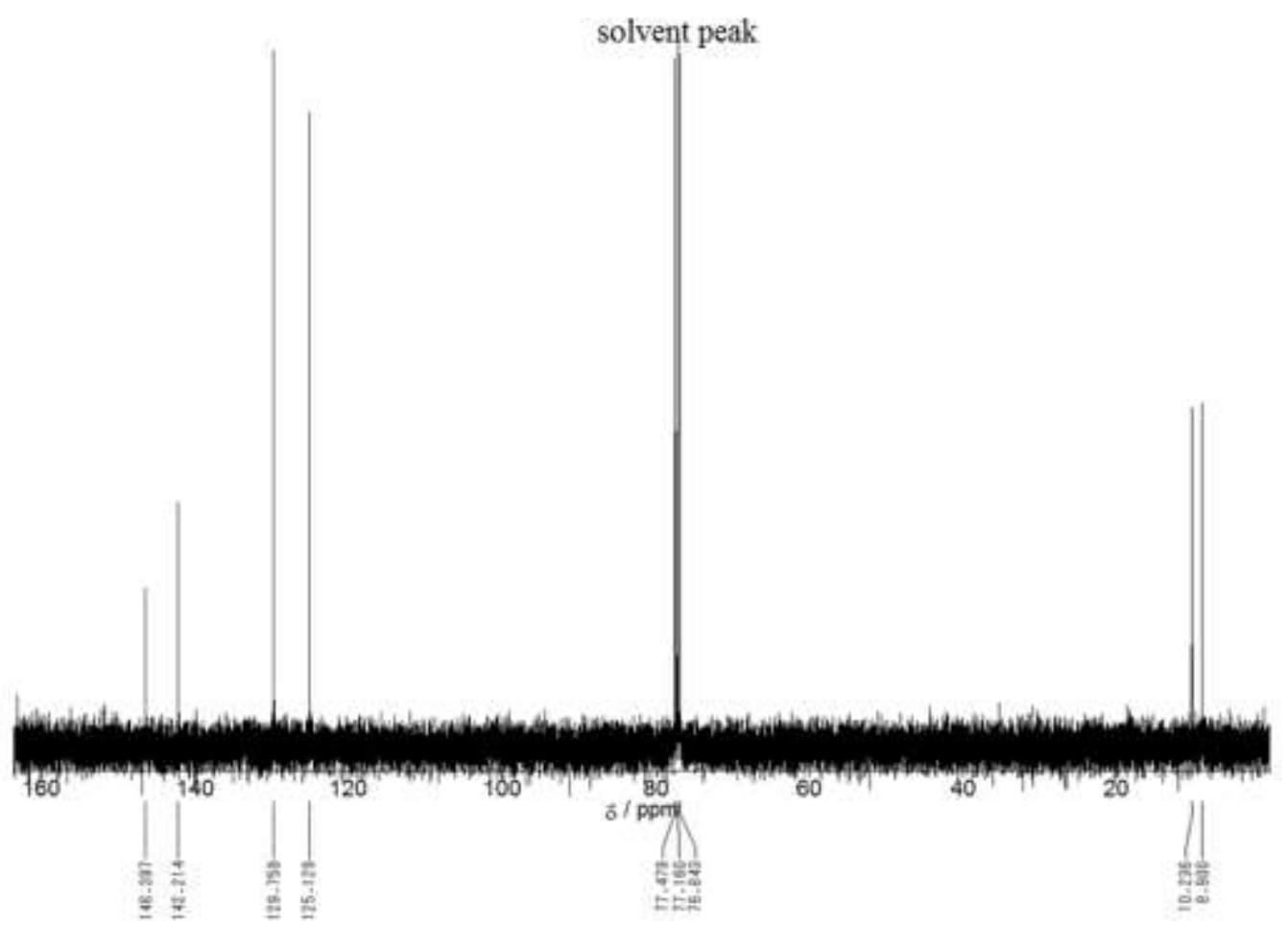

Figure S17. ${ }^{13} \mathrm{CNMR}$ spectrum of dDTGH in $\mathrm{CDCl}_{3}$. 


\section{FRONTIER ORBITAL PROFILES}

DTG-H
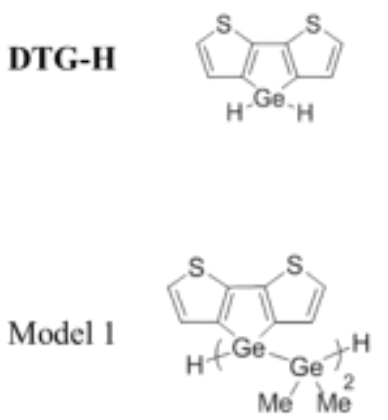

Model 2

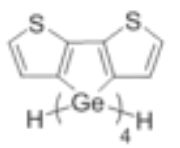

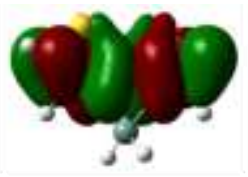
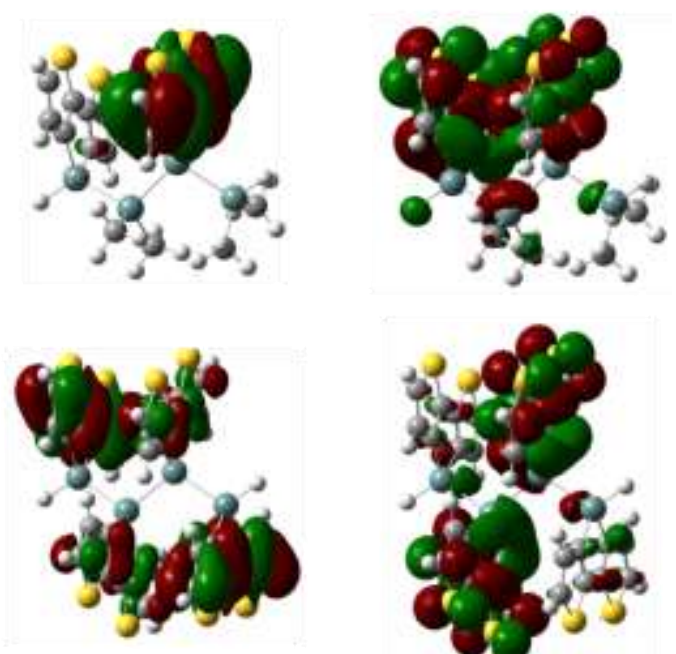

HOMO
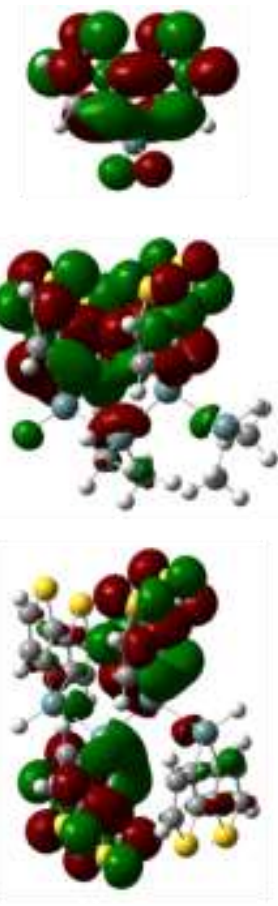

LUMO

Figure S18. Frontier orbitals of DTG, model 1, and model 2 based on DFT calculations at the B3LYP/6-31G(d) level.

\section{UV-VIS ABSORPTION AND PL SPECTRA}

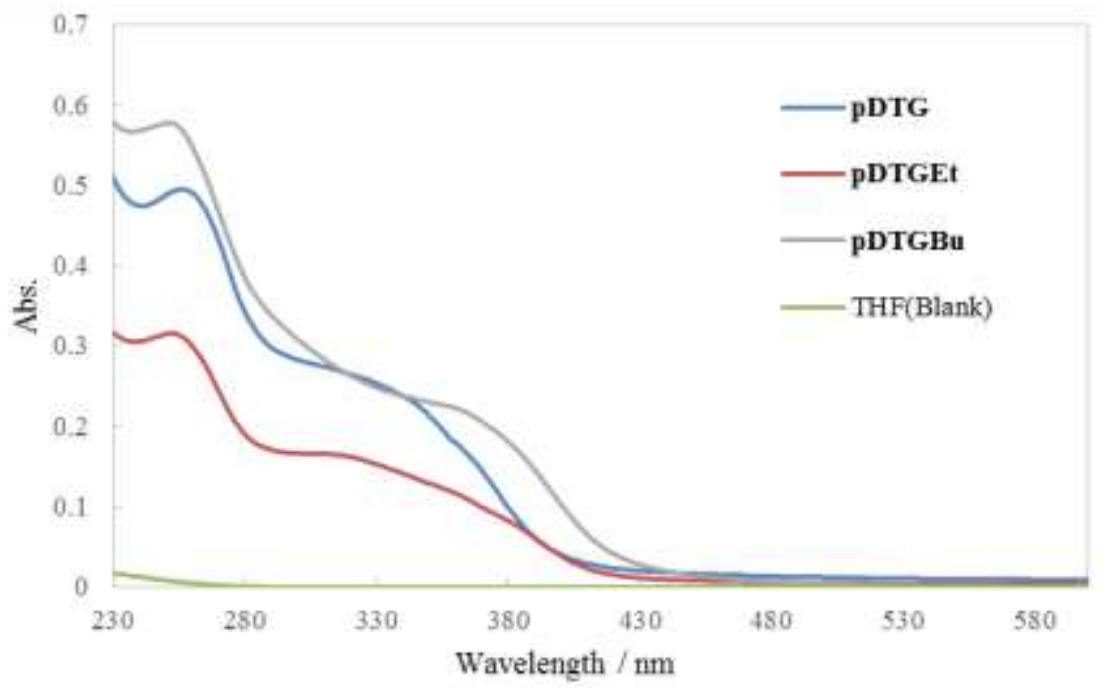

Figure S19. UV-vis absorption spectra of pDTG, pDTGEt, pDTGBu, and THF (Blank). 


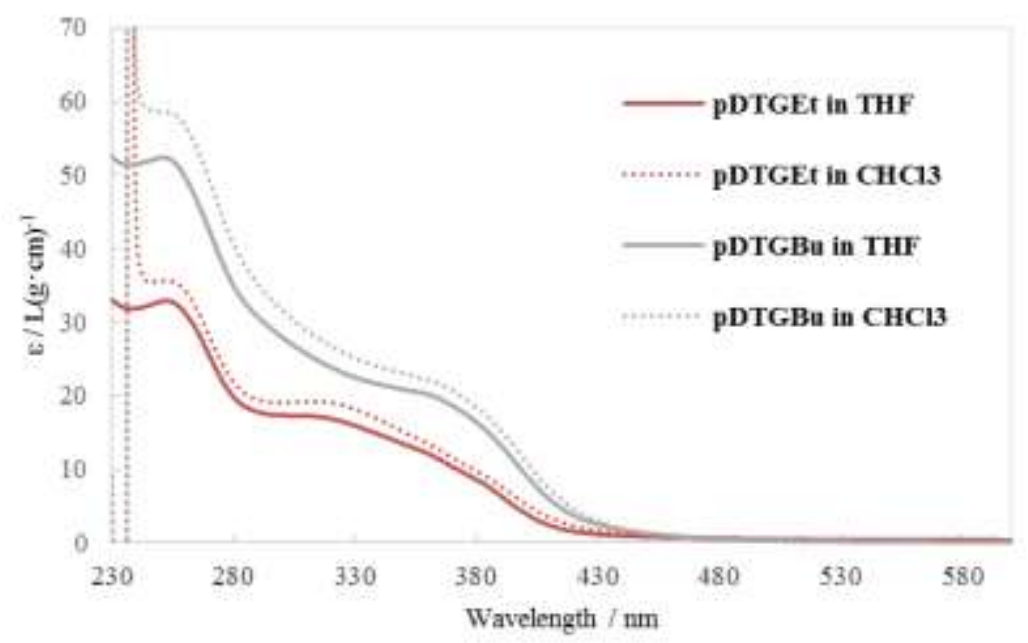

Figure S20. UV-vis absorption spectra of pDTGEt and pDTGBu in THF or $\mathrm{CHCl}_{3}$.

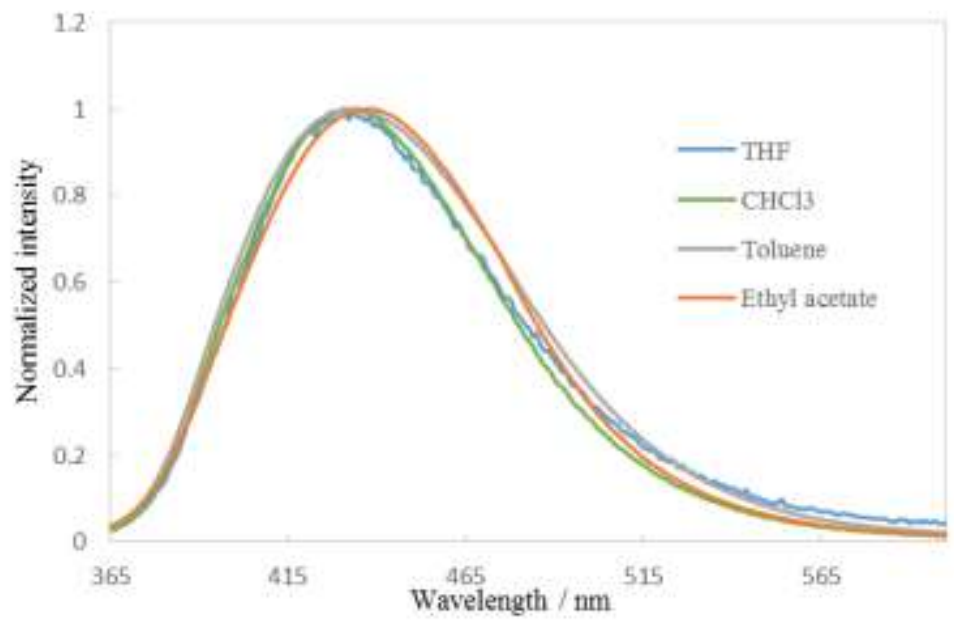

Figure S21. PL spectra of pDTGEt in various solvents.

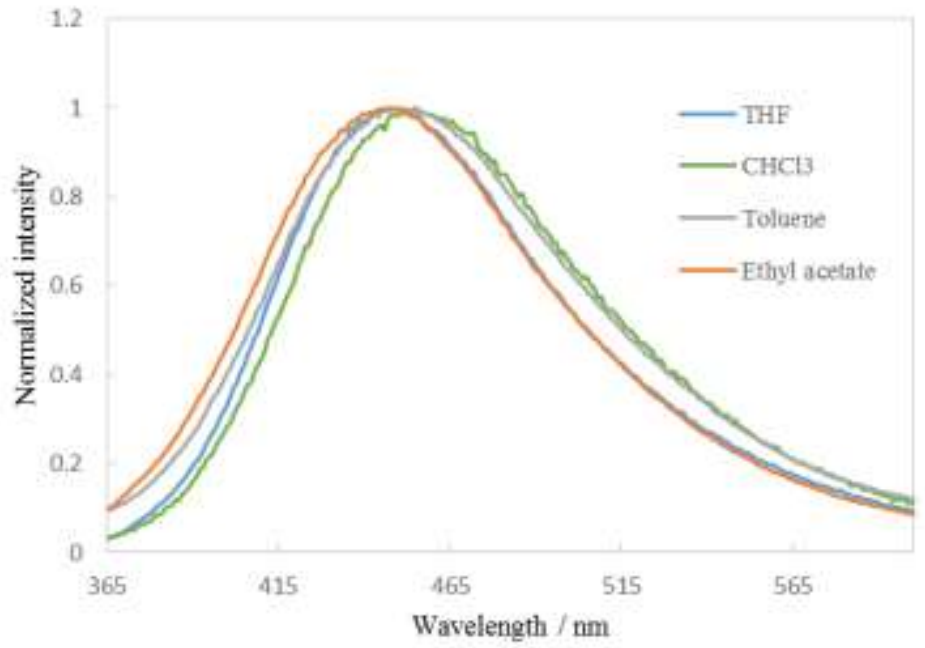

Figure S22. PL spectra of pDTGBu in various solvents. 